Nowak K. (2014). Advanced Private Banking in Terms of Ecology. Copernican Journal of Finance \& Accounting, 3(2), 91-109. http://dx.doi.org/10.12775/CJFA.2014.020

\author{
KAMIL NOWAK* \\ Nicolaus Copernicus University
}

\title{
ADVANCED PRIVATE BANKING IN TERMS OF ECOLOGY
}

Keywords: private banking, sustainable investment funds, social responsible investing.

\section{J E L Classification: G21.}

Abstract: In recent years it has been observed that financial institutions have become aware of the social responsibility of businesses and in particular, the attention has been drawn to ecology. The purpose of this paper is to present the highest, third level of involvement of financial institutions in Ecology. Paper looks into sustainable investing through private banking sector. Financial institutions analyzed in this paper were chosen due to exquisite approach to the environment protection. The article analyses the advanced and innovative solutions introduced by private banking for the benefit of the protection of natural surroundings.

\section{ZAAWANSOWANA BANKOWOŚĆ PRIVATE W UJĘCIU EKOLOGICZNYM}

Słowa kluczowe: bankowość prywatna, inwestowanie społecznie odpowiedzialne, odpowiedzialne fundusze inwestycyjne.

Klasyfikacja J E L: G21.

Abstrakt: W ostatnich latach obserwuje się coraz większe zainteresowanie instytucji finansowych społeczną odpowiedzialnością biznesu, a szczególnie problemami środowiska naturalnego. Celem niniejszej publikacji jest przedstawienie najwyższego

Date of submission: March 31, 2014; date of acceptance: October 3, 2014.

* Contact information: k.nowak@doktorant.umk.pl, Faculty of Economic Sciences and Management, Nicolaus Copernicus University, Gagarina 13a, 87-100 Toruń, Poland, phone: 566114634 . 
- trzeciego poziomu zaangażowania instytucji finansowych w ekologię. Artykuł opisuje zrównoważone inwestowanie przez pryzmat sektora bankowości prywatnej. Instytucje finansowe analizowane w niniejszej publikacji zostały wybrane ze względu na wyjątkowe podejście do problemów środowiska naturalnego. W artykule dokonano analizy zaawansowanych oraz innowacyjnych rozwiązań stosowanych w czołowych instytucjach private banking na rzecz ochrony środowiska naturalnego.

\section{INTRODUCTION}

Care for the environment is not only the responsibility of governments or institutions serving this purpose. It has become a vital element of every business activity. The society expects companies to function responsibly, taking into account economic, social and environmental problems. A company is expected to have a positive influence on the surroundings i.e. community and natural environment. Customers of financial institutions require a degree of social responsibility from their partners. More often than not, customers are interested in ecology and protection of natural environment. Financial institutions to cater for the needs of their customers and achieve advantage over the rival companies become interested in the protection of the natural environment. The greatest requirements are faced by private banking institutions due to the most demanding customers they serve. In response to their customers' expectations, private banking institutions have developed innovative solutions for natural environment issues applied in the marketing of an institution and preparing offers of environmentally friendly projects and services. This paper aims to present and analyze the involvement of private banking in the natural environment problems through advanced service offers.

\section{THE RESEARCH METHODOLOGY}

\section{AND THE COURSE OF THE RESEARCH PROCESS}

The paper contains descriptive research studies carried out in several steps. First step defines consumer segmentation in private banking. Than presents involvement of financial institutions in the protection of the environment on different levels. Finally paper focuses on highest level of ecological involvement and analyzes eco-oriented solutions in the top private banking institutions. The study ends with conclusions achieved by analyzing reports and surveys conducted by financial and research institutions. 


\section{CONSUMER SEGMENTATION IN PRIVATE BANKING}

The basic criterion for defining a private banking customers is their wealth. A wealthy customer is a customer owning over 1 million USD worth of assets (World Wealth Report 2013, 4). The wealthy customers group is the most attractive for the banking sector and is named High-Net-Worth Individuals (HNWI). Figure 1 shows the dynamics of changes in the world's HNWI population between 2007-2012 in different regions. In three form five analysed years, there is a visible upward trend. In 2012 the global population of wealthy individuals was 12 million, which is 9,2\% more than in the previous year. The biggest growth dynamics of HNWI can be observed in North America, Africa and Asia. The European HNWI population has grown slightly more than the world's average $-9,4 \%$.

Figure 1. HNWI Population, 2007- 2012 (by Region)

(Million)

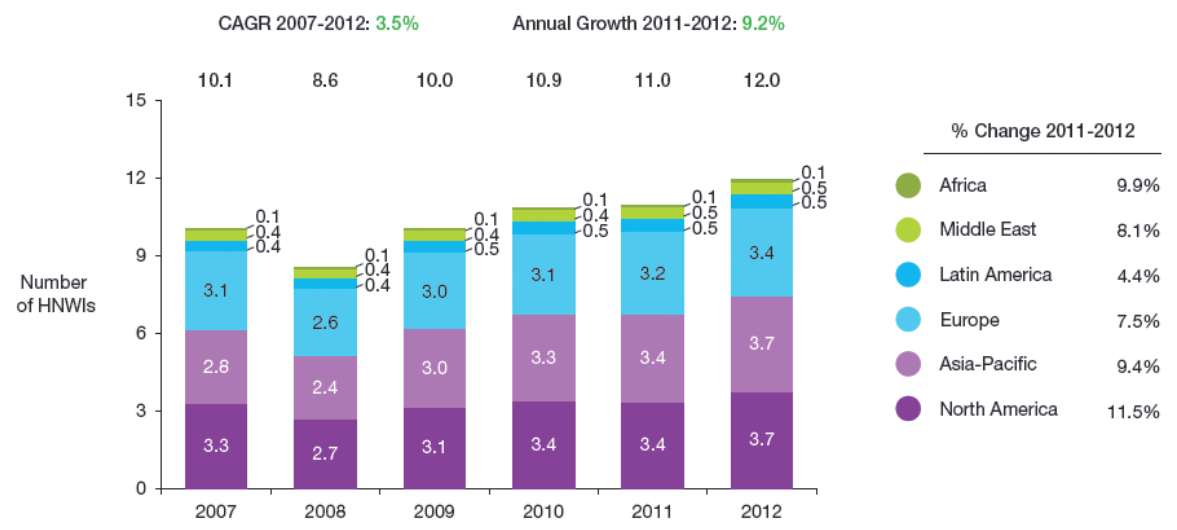

S o u r c e : World Wealth Report 2013, 5. 
Figure 2. HNWI Wealth Distribution, 2007 - 2012 (by Region)

\section{(US\$ Trillion)}

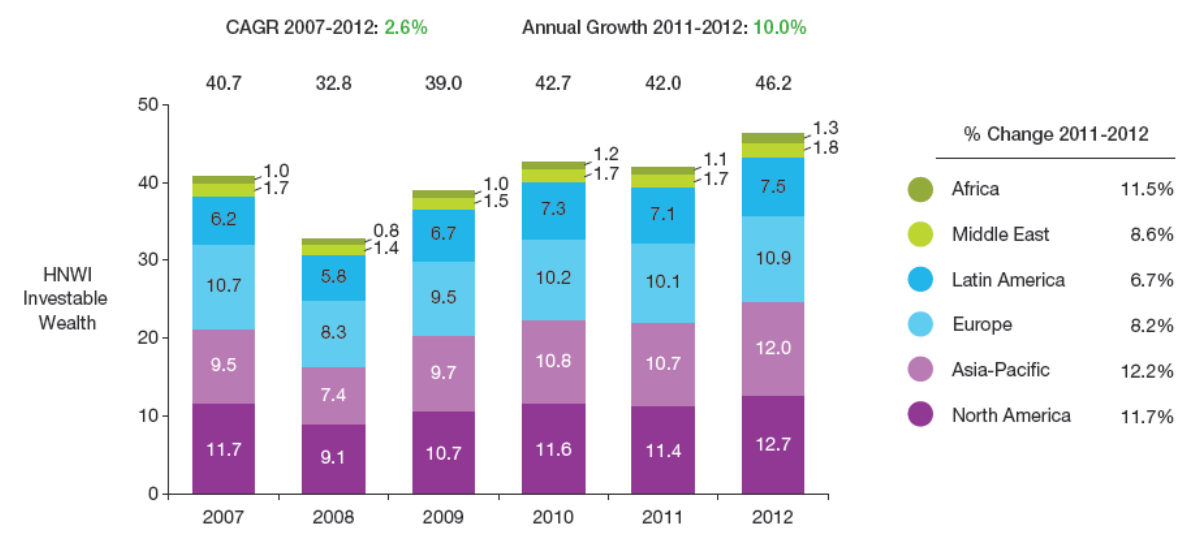

S o u r c e : World Wealth Report 2013, 5.

Figure 2 presents the investible wealth dynamics as displayed by HNWI between 2007 and 2012, in regions. After the decline in the investible wealth in 2008 caused by economic crisis, years 2009 and 2010 show a steady growth back to the level from 2007. 2012 was a year of 10\% growth in the investible wealth comparing with 2011. At present, HNWI is estimated at US\$46.2 trillion. The analysis of the private banking sector customers and their investible wealth shows how big this segment is. For that reason, this group is a highly desirable customer for the banking sector. Consequently, the wealthy costumer group is the most demanding group for banking. Due to the wealth at disposal, HNWI apart from securing and investing the assets (Dziawgo 2005, 35), also expect high quality service, qualified personnel and accounting for their individual suggestions. Personal preference may affect the financial product offer, service and the image of a banking institution (Dziawgo 2005, 67). Customers may choose a bank which suits their personal preferences and they have a wide variety of banking institutions to choose from. In the recent years, a growth in Corporate Social Responsibility has been clearly visible. The CSR often becomes a major factor influencing the choice of a financial partner. Therefore, the activity connected with CSR may be an important element in achieving a competitive advantage over rival institutions. CSR may be realised in social, ethical, religious and ecological aspects (Dziawgo 2010,16). Islamic banking is an interesting example of CSR realised in religious terms. However, ecology and 
environmental protection tend to be the most popular subject of CSR stemming from the popular interest in these issues.

In the investment activity, CSR is realised in terms of Social Responsible Investing. SRI strategy takes into account environmental, social end economic problems at an every stage of the investment process. Ecological and social factors are a basis for decision making, from the stage of choosing the assets to making use of the ownership rights and responsibilities (Krosinsky, Robins 2008, 14-15).

\section{DEVELOPMENT OF Social ReSPONSIBLE INVESTING}

When SRI in USA, UK and Western Europe is thriving than it is emerging in Australia, Asia and other European countries. Sparks claims that Socially Responsible Investing develops rapidly and may revolutionize global finance. Despite impressive growth of SRI in last decades it is still a finacial niche (Sparkes 2002, 22-26). In present form sustainable investing lack the power of significant change in the context of natural environment problems (Haigh, Hazelton 2004, 61). Haigh and Hazelton questions SRI funds performance. In their innovative paper they claims that both customers and suppliers of SRI fund are not motivated by prospects of return. Most of investors invest only small part of assets in SRI funds, which is the way to clear customer's conscience (Haigh, Hazelton 2004, 65). Different, more positive and optimistic for SRI point of view is presented by Jeucken. The author analyzed the term of SRI in the context of economic theory. His work mostly focuses on banking sector and environment friendly finance products development. Jeucken narrowed down broad sustainable finance to sustainable banking.

\section{THE INVOLVEMENT OF PRIVATE BANKING SECTOR IN THE PROTECTION OF THE ENVIRONMENT}

The involvement of financial institutions in the environmental protection can be observed directly in the business activity or in projects not directly connected with it.

The first type of engagement involves:

- founding projects of low environmental risk;

- offering products and services supporting environment protection;

- eco-oriented management; 
- marketing;

- public relations;

- investor relations.

Ecological sponsorship is an example of a non-business activity (Dziawgo $2010,35)$. Activities for natural environment protection and their effects vary. These differences should be classified. Professor Dziawgo attempted to classify the eco-oriented business activity of financial institutions in terms of hierarchy (Dziawgo 2003, 18-21).

Schema 1. The hierarchy of activities

of a financial institution for natural environment protection

LEVEL III

(the highest)

An offer connected with the financing of natural environment protection at one's disposal

LEVEL II

LEVEL I

Sponsoring, public relations, marketing

Organisation of labour and economic process with the requirements of natural environment protection taken into account, including ecological risk in financial operations

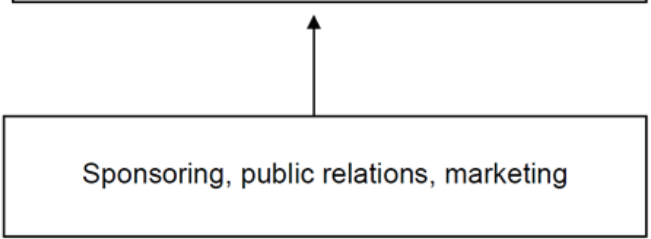

S o u r c e: Dziawgo 2003, 20.

The lowest level of engagement in the natural environment protection is the activity not directly connected with the business activity of a financial institution i.e. sponsoring ecological projects, marketing and public relations. The next level of engagement is ecological management of assets, limiting pollution, accounting for the ecological risk while making decisions connected with financing a business activity. The highest level of the involvement is defined as directly connected with the financial activity by Professor Dziawgo. The offer of products and services aiming at leveraging assets for financing eco-friendly 
projects and launching them is a basis. The highest level of engagement in natural environment protection is an excellent example of using financial market as a means of improvement of the natural environment state which results also in gaining profit (Dziawgo 2010, 38-40). The business activity of financial institutions connected with the eco-oriented economy can be divided into 4 groups, as classified by Marcel Jeucken :

- Investing bank's investment capital or pension portfolio in a sustainable way or in sustainable projects;

- Linking traditional products to sustainable cause by a way of donations;

- Developing new product meeting environmental and social criteria;

- Developing products collaborating with governments (Jeucken 2004, 232-233).

The topic of the above mentioned paper is the presentation of eco-oriented solutions in the private banking sector - Swiss UBS and German Deutsche Bank, at the highest -third level of involvement in natural environment protection.

\section{VALUE-BASED INVESTING IN UBS}

The Swiss bank UBS has a 15 years experience in CSR. Social responsibility of this financial institution connected with private banking sector is displayed in Social Responsible Investing. In UBS, SRI strategy is called VBI (Value-Based Investing). This investment philosophy aims at securing profit from the invested assets and at the same time solving the biggest environmental and social problems of the XXI century i.e. climate changes, aging of society, shortage of fresh water. UBS Wealth management customers interested in SRI are offered individual investment counselling based on VBI, with the purpose of achieving a certain return of investment with consideration for the impact on the society and the natural environment. Current and future customers are offered UBS Portfolio Screening Services, which aim at determining the inconsistency and adjusting the portfolio for the personal preferences of an SRI customer. In 2012 a total of CHF 1,2 billion worth of assets have been screened. Accounting for different SRI preferences of customers, UBS offers 4 strategies for creating an individual investment portfolio presented in schema 2 . 
Schema 2. Different VBI strategies that can be combined

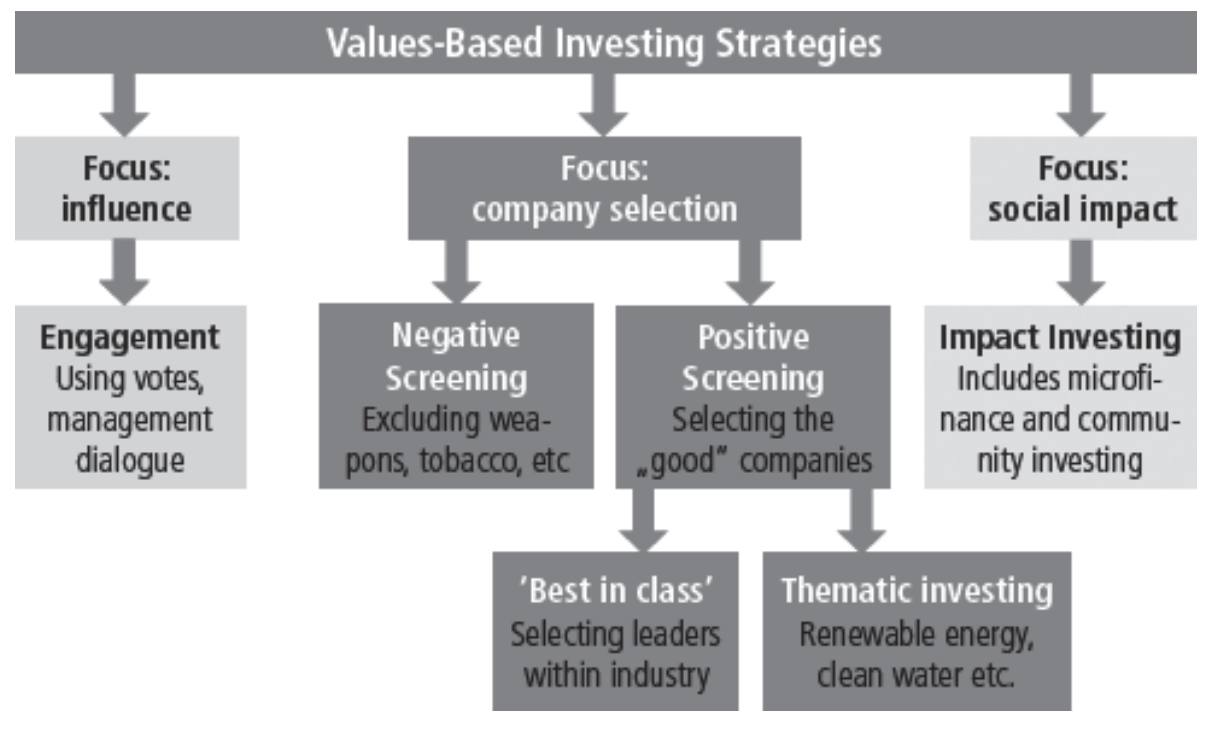

S o u r c e : UBS.

When it comes to choosing the assets of companies incorporated in an investment portfolio, UBS offers two strategies: negative screening and positive screening. Negative screening aims at excluding from the portfolio assets or whole economy sectors inconsistent with the customer's ethics. Frequently, among these assets are those of companies whose activity has a negative impact on the natural environment or business institutions connected with defence, alcohol or tobacco industry. The main advantages of negative screening are low labour and time costs. Nevertheless, it has to be remembered that excluding whole sectors of economy can disturb the benchmark of an investment portfolio. Another activity offered by UBS - positive screening aims at investing in companies which have a positive influence on natural environment and society. An investment portfolio can be created on the basis of this strategy using 2 methods Best-In-Class and Thematic investing. Best-In-Class chooses financially attractive companies which are CSR leaders in their trade. Best-InClass allows constructing a diverse low-risk portfolio. A major disadvantage of this method is the necessity of detailed screening of a company to exclude the unfair and unethical areas of its business activity. Thematic investing is mainly focused on companies offering innovative CSR solutions interesting for the customer, such as the shortage of fresh water or the use of renewable energy. 
Thematic investing mainly concerns small and medium-size institutions. The advantages of this method are financing projects lying within an interest area of a customer and potentially high investment return. However, investing in the SME sector involves high risk. For this reason, thematic investing should serve as complementation of an investment portfolio accounting for the individual customer preferences. The strategy aiming to influence decision processes of a company - subject of an investment- so that it is directed at social responsibility is the strategy of engagement. Owning a significant block of shares, an investor can influence the decisions of the board of executives and use the right to vote so that CSR plays a major role in the company. The advantage of Engagment strategy is the possibility to apply it for every investment portfolio. However, the predicted effects of the involvement of an institution in CSR are not measurable. Impact Investing offers a possibility of engagement in micro-scale projects, directly influencing certain communities such as financing social initiatives or supporting small local companies. This is the riskiest strategy offering relatively low investment return.

\section{UBS PRODUCTS BASED ON VALUE-BASED INVESTING}

Apart from individual investment strategies, UBS offers ready-made products such as investment funds: Sustainable \& Responsible Funds registered in Luxemburg. The process of the selection of assets for these investment portfolios is based on two types of companies: leaders and innovators. Companies best in their trade in terms of CSR are considered leaders. The selection of these assets is conducted with the use of Best-In-Class strategy. Innovators are small companies starting their activity, offering innovative products and services. Leaders are usually international corporations guarantying a high investment return, while innovators offer a high investment potential at a higher risk.

\section{UBS (Lux) Climate Change}

A fund investing assets into small companies connected with renewable energy, alternative sources of energy and energy management. In February 2014, this fund had a EUR 90 mln worth of assets. Table 1. present the geographic and sector structure of the fund and 10 largest companies in this investment portfolio. 
Table 1. UBS (Lux) Climate Change Fund structure

Country exposure $(\%)$

\begin{tabular}{l|l}
\hline & \multicolumn{1}{c}{ Fund } \\
\hline United States & 10.3 \\
\hline China & 9.3 \\
\hline France & 6.9 \\
\hline Italy & 6.4 \\
\hline Germany & 6.1 \\
\hline Japan & 6.0 \\
\hline Republic of Korea & 4.1 \\
\hline United Kingdom & 3.2 \\
\hline Hong Kong & \\
\hline Others & \\
\hline
\end{tabular}

Sector exposure $(\%)$

\begin{tabular}{l|l}
\hline Services \& products & \multicolumn{1}{l}{ Fund } \\
\hline Transport & 18.6 \\
\hline Building \& lighting & \\
\hline Production \& transmission & 13.0 \\
\hline Other renewable energy & 11.9 \\
\hline Wind energy & 6.9 \\
\hline Alternative energy & 1.7 \\
\hline Solar energy & 0.0 \\
\hline
\end{tabular}

10 largest equity positions (\%)

\begin{tabular}{|c|c|c|c|}
\hline & Fund & & Fund \\
\hline China Suntien Green Energy Corp & 4.00 & Valeo SA & 3.20 \\
\hline Emerson Electric Co & 3.34 & EDP Renovaveis & 2.97 \\
\hline IPG Photonics Corp & 3.26 & MYR Group Inc/Delaware & 2.57 \\
\hline
\end{tabular}

S o u r c e : UBS Fund Sheet.

American services sector companies are in the portfolio of the UBS Climate Change fund.

\section{UBS (Lux) Eco Performance}

This oldest CSR UBS fund has been on the market since 1996. UBS (Lux) Eco Performance invests in the shares of large cap companies displaying an above average engagement in the social and natural environment protection issues. According to table 2., UBS Eco Performance invests mainly in big American companies from various sectors of economy. Apple and Amazon are among the top ten investment companies in this fund. In February 2014 the assets of this fund were worth more than EUR $102 \mathrm{mln}$. 
Table 2. UBS (Lux) Eco Performance structure

Country exposure $(\%)$

\begin{tabular}{l|l}
\hline & \multicolumn{1}{l}{ Fund } \\
\hline United States & \\
\hline Japan & 12.6 \\
\hline Germany & 6.1 \\
\hline United Kingdom & 5.9 \\
\hline France & 3.4 \\
\hline Netherlands & 2.9 \\
\hline Sweden & 2.7 \\
\hline Switzerland & 2.7 \\
\hline Norway & \\
\hline Others &
\end{tabular}

10 largest equity positions (\%)

\begin{tabular}{|c|c|c|c|}
\hline & Fund & & Fund \\
\hline US Bancorp & 2.85 & Alnylam Pharmaceuticals Inc & 2.26 \\
\hline Amazon.Com Inc & 2.72 & Macy's Inc & 2.13 \\
\hline Mondelez International Inc & 2.63 & Broadcom Corp & 2.07 \\
\hline Norfolk Southern Corp & 2.35 & Procter \& Gamble Co & 2.05 \\
\hline Apple Inc & 2.30 & Nordea Bank AB & 1.95 \\
\hline
\end{tabular}

S o u r c e : UBS Fund Sheet.

\section{UBS (Lux) Emerging Markets Innovators}

This fund invests in the assets of small emerging market companies which use modern technological solutions for mitigation of climate change, solving the problem of shortage of fresh water or problems connected with the concept of sustainable development. The portfolio is created on the basis of the economic analysis and on the social and environmental criteria. UBS Emerging Markets Innovators invests mainly in Asian companies dealing with the issue of sustainable development and climate change. In February 2014 the fund had the capital of EUR $86 \mathrm{mln}$. 
Table 3. UBS (Lux) Emerging Markets Innovators structure

Country exposure $(\%)$

\begin{tabular}{l|l}
\hline \multicolumn{2}{l}{ Fund } \\
\hline China & \\
\hline Republic of Korea & \\
\hline Brazil & \\
\hline India & 16.7 \\
\hline Taiwan & 7.1 \\
\hline Mexico & 4.7 \\
\hline South Africa & 3.5 \\
\hline Sweden & 3.0 \\
\hline Indonesia & $\square_{2.4}$ \\
\hline Others & \\
\hline
\end{tabular}

10 largest equity positions (\%)

\begin{tabular}{lr}
\hline & Fund \\
\hline WUXI PHARMATECH INC-ADR & 3.46 \\
\hline CHINA SUNTIEN GREEN ENERGY H & 3.13 \\
\hline NEW ORIENTAL EDU \& TECH GRP ADR & 3.06 \\
\hline HCL TECHNOLOGIES IND2 & 3.02 \\
\hline MILLICOM INTL CELLULAR SA & 2.96 \\
\hline
\end{tabular}

S o u r c e : UBS Fund Sheet.
Sector exposure (\%)

\begin{tabular}{l|l}
\hline \multicolumn{1}{c}{ Fund } \\
\hline Sustainable Development & \\
\hline Climate change & \\
\hline Water & 6.4 \\
\hline Others & 3.0 \\
\hline
\end{tabular}

\section{UBS (Lux) Global Innovators}

This fund invests in the assets of small and medium size companies (mainly American ones) developing technologies connected with the issue of climate change or demographic changes. In February 2014, it had EUR 57 mln worth of capital. The geographic and sector structure and 10 prevalent companies are presented in table 4.

Table 4. UBS (Lux) Global Innovators structure

Country exposure $(\%)$

\begin{tabular}{l|l}
\hline & \multicolumn{2}{c}{ Fund } \\
\hline United States & 8.5 \\
\hline Republic of Korea & 8.0 \\
\hline France & 6.0 \\
\hline Japan & 3.3 \\
\hline United Kingdom & 3.3 \\
\hline Italy & 3.2 \\
\hline China & 2.7 \\
\hline Brazil & 2.6 \\
\hline Canada & \\
\hline Others & \\
\hline
\end{tabular}

10 largest equity positions (\%)

\begin{tabular}{lr}
\hline & Fund \\
\hline Valeo SA & 4.02 \\
\hline IPG Photonics Corp & 3.71 \\
\hline CF Industries Holdings InC & 3.54 \\
\hline SFA Engineering Corp & 3.41 \\
\hline Soulbrain Co Ltd & 3.17 \\
\hline
\end{tabular}

\begin{tabular}{lr} 
& Fund \\
\hline Jones Lang LaSalle Inc & 2.95 \\
\hline LSB Industries Inc & 2.92 \\
\hline Alnylam Pharmaceuticals InC & 2.86 \\
\hline Aberdeen Asset Management PLC & 2.39 \\
\hline Emerson Electric Co & 2.33 \\
\hline
\end{tabular}

\begin{tabular}{lr} 
Sector exposure (\%) & Fund \\
\hline Climate change & 51.6 \\
\hline Demographics (nutrition/healthcare) & 32.4 \\
\hline Water & 14.1 \\
\hline Others & 1.9 \\
\hline
\end{tabular}

Emerson Electric Co

S o u r c e : UBS Fund Sheet.

Fund

SAMSUNG ELECTRONICS KRW5000

TAIWAN SEMICONDUCTOR TWD10

2.45 


\section{UBS (Lux) Sustainable Global Leaders}

This fund had EUR 155 mln capital. It invests in global large cap companies (mainly American) which are leaders in their trade. These companies offer innovative products and services that may serve as a solution for the challenges of the concept of sustainable development. Table 5. presents the geographic and sector structure of the fund together with 10 most important companies like Apple, CVS or General Electric.

Table 5. UBS (Lux) Sustainable Global Leaders structure

\begin{tabular}{l|l} 
Country exposure (\%) & Fund \\
\hline & \\
\hline United States & 8.3 \\
\hline United Kingdom & 7.9 \\
\hline Japan & 7.4 \\
\hline Netherlands & 6.6 \\
\hline France & 6.5 \\
\hline Switzerland & 3.4 \\
\hline Canada & 3.0 \\
\hline Germany & 1.9 \\
\hline Hong Kong & 2.3 \\
\hline Others &
\end{tabular}

\begin{tabular}{lr} 
Sector exposure (\%) & Fund \\
\hline Climate change & 47.8 \\
\hline Demographics (nutrition/healthcare) & 26.7 \\
\hline Sustainable Development & 9.9 \\
\hline Water & 9.8 \\
\hline Others & 5.9 \\
\hline
\end{tabular}

10 largest equity positions (\%)

\begin{tabular}{|c|c|c|c|}
\hline & Fund & & Fund \\
\hline McKesson Corp & 3.62 & Denso Corp & 2.97 \\
\hline Canadian Pacific Railway Ltd & 3.24 & Muenchener Rueckversicherungs AG & 2.84 \\
\hline Danaher Corp & 3.10 & Apple Inc & 2.59 \\
\hline
\end{tabular}

S o u r c e : UBS Fund Sheet.

\section{RESPonsible BANKING IN DEUTSChe BANK}

Responsible banking in German Deutsche Bank is based on the concept of ESG (Environmental, Social and Governance). ESG, similar to SRI, takes into account social, environmental factors and corporate governance in the investment process (Dziawgo 2010,17). The work of Wealth Management in Deutsche Bank relies on ESG and UN initiative - Principles of Responsible Investment (PRI). Investment portfolios are created on the basis of the assessment of potential investment return and investment risk as presented in ESG rating, which is created by Oekom Research- an agency specialising in socially responsible investments. Next, assets are selected using Best-In-Class strategy. The strategy takes into account individual customer preferences for the investments. Deut- 
sche Bank has also prepared Philanthropic Wealth Management and Individually Tailored Products offer which allow wealthy investors to directly realise projects connected with natural environment protection (e.g. photovoltaic farms, "green" properties) chosen with regard of the customers individual criteria.

Deutsche Bank offers also a wide variety of responsible investment funds financially connected with DWS. According to the end-of-year 2013 data DWS possesses a EUR 3.72 billion worth of assets, meeting the ESG criteria.

\section{DWS Sustainable Funds}

\section{DWS Invest Clean Tech (former Climate Change)}

This fund invests capital in national and global companies producing renewable energy (solar, wind, water and biomass energy). Companies trading in the ecological transfer of energy and the development of energy-effective technologies are also subjects of investment for this fund. In February 2014, DWS had EUR 10.09 mln capital. Figure 3 shows the geographic and sector structure of the fund with its most important companies. American, Japanese and German industrial and IT institutions prevail.

Figure 3. DWS Invest Clean Tech structure

\section{Largest individual positions by sector}

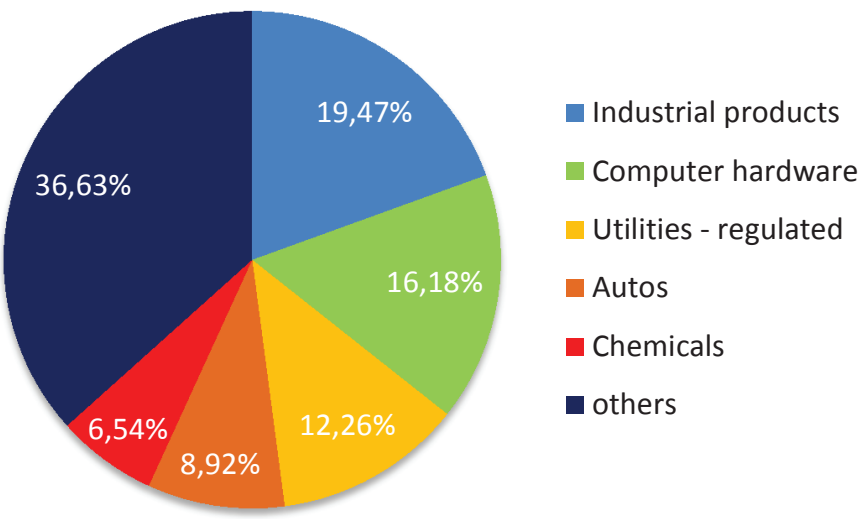




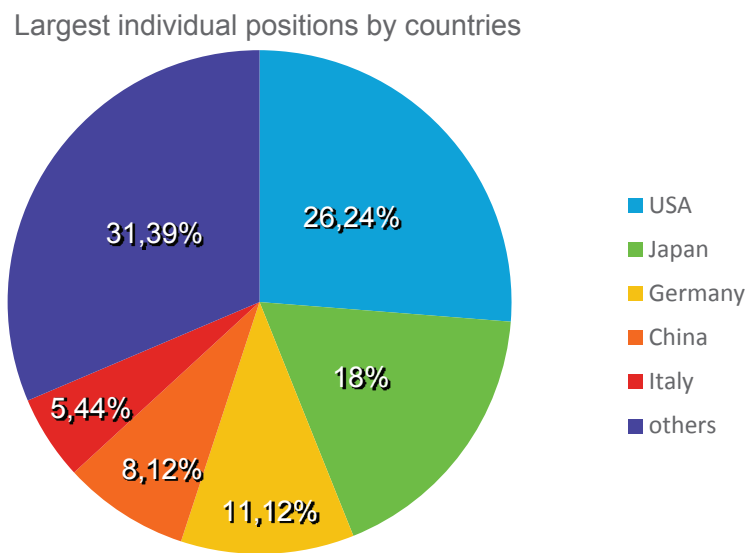

Largest individual positions by shares

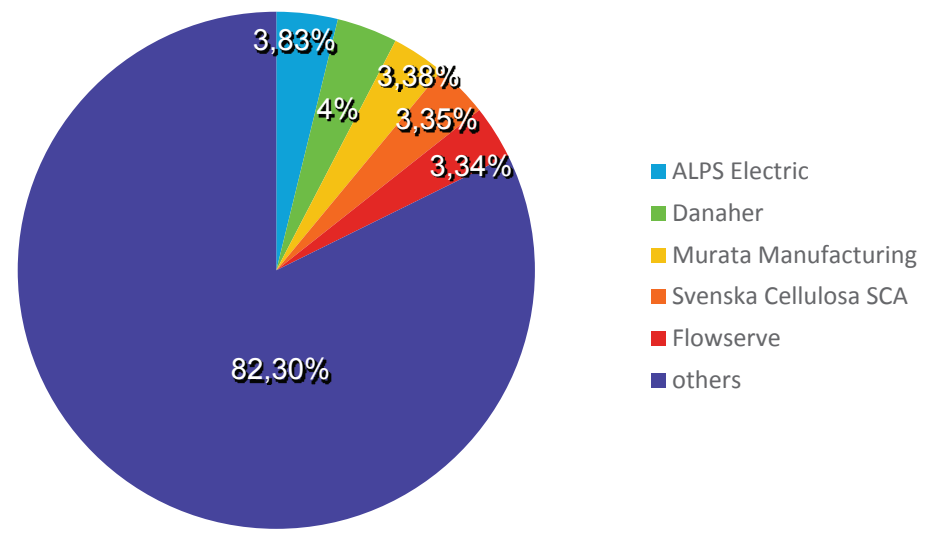

S o u r c e : www.sustainable-investment.org.

\section{DWS Water Sustainability Fund (former Klimawandel)}

This fund has been operating on the market since 2010. It invests in the shares of German and foreign companies active in the field of limiting $\mathrm{CO} 2$ emissions, gaining and using renewable energy and energy-efficient technologies. Companies invovled in the protection of climate, eco-friendly energy-efficient transport are also subjects of the fund investment. In February 2014, the capital of the fund amounted to EUR $61 \mathrm{mln}$. Figure 4 presents the geographic and sector structure of the fund, together with the most important companies in the portfolio. DWS Water Sustainability invests mainly in industrial and public sector in the USA, Switzerland and UK. 
Figure 4. DWS Water Sustainability Fund structure

Largest individual positions by sector

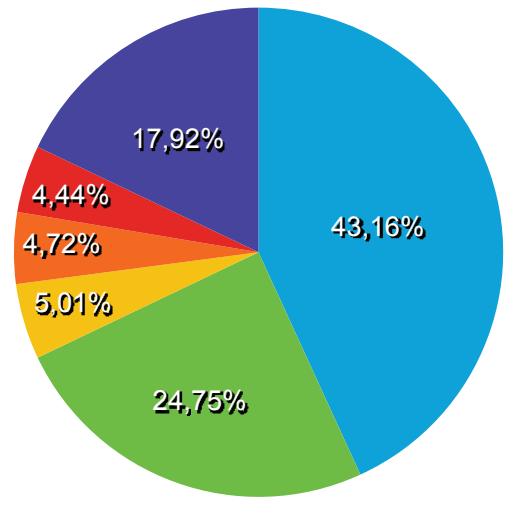

Largest individual positions by countries

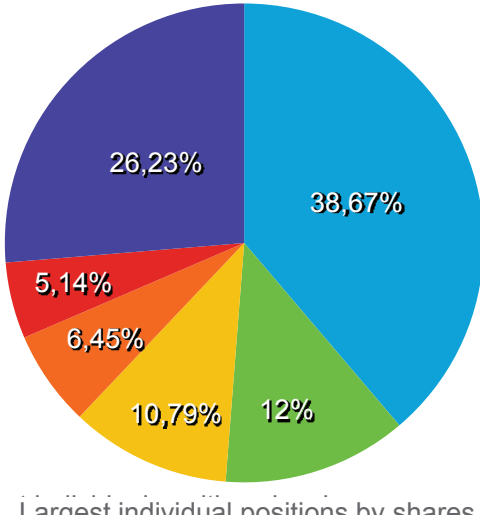

Largest individual positions by shares

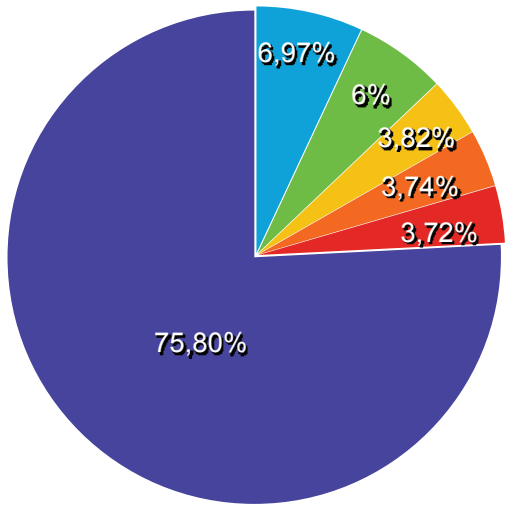

S o u r c e : www.sustainable-investment.org.
- Industrial products

- Utilities - regulated

Waste Management

- Chemicals

Engineering and Construction

- others

- USA

Switzerland

United Kingdom

- France

- Japan

a others

- Pentair

- Danaher

- CDSBDE

- Suez Environnement

- United Utilities

- others 


\section{DWS Zukunftsressourcen}

This fund was launched in 2006. In February 2014, it had assets worth EUR $269 \mathrm{mln}$. According to the strategy of the fund, at least $51 \%$ of the assets should be invested in German and foreign companies operating in the sector connected with water, agrochemistry and renewable energy. Only companies with $20 \%$ income coming from these areas qualify for the portfolio of this fund. Figure 5 shows the geographic and sector structure of the fund together with its most important companies DWS Zukunftsressourcen invests mainly in the industry in the USA and Japan.

Figure 5. DWS Zukunftsressourcen structure

Largest individual positions by sector

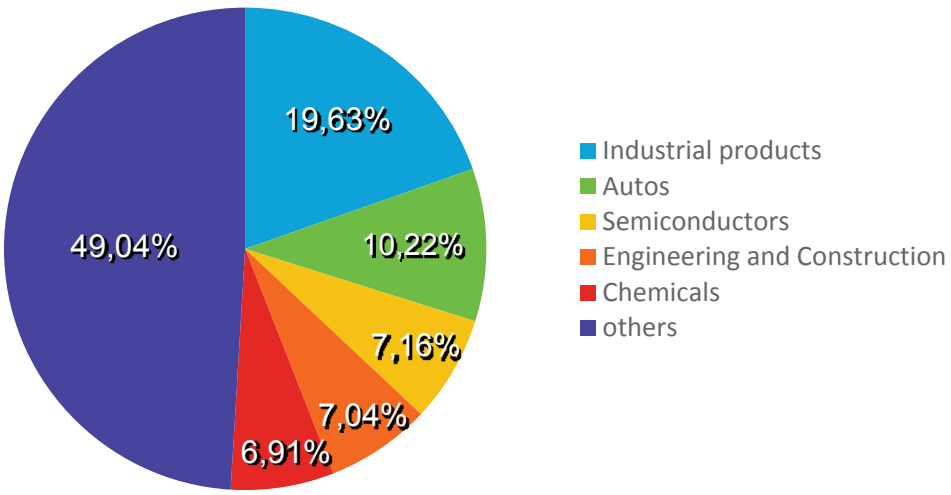

Largest individual positions by countries

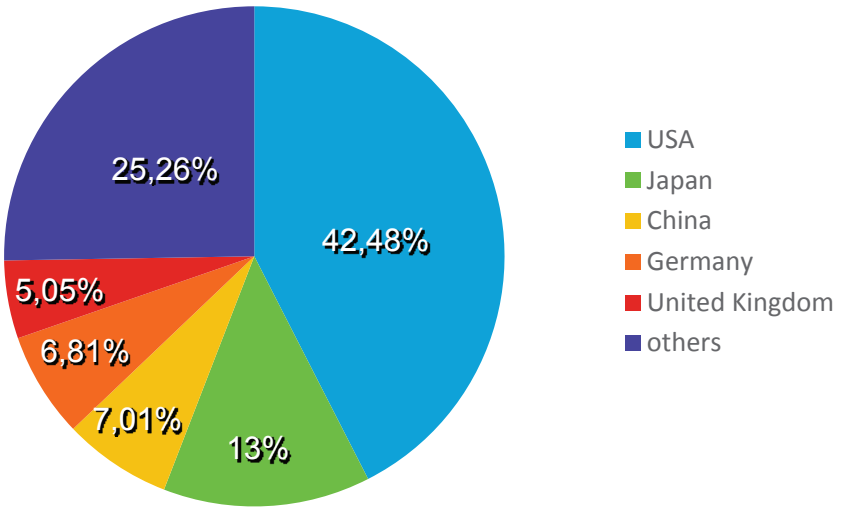


Largest individual positions by shares

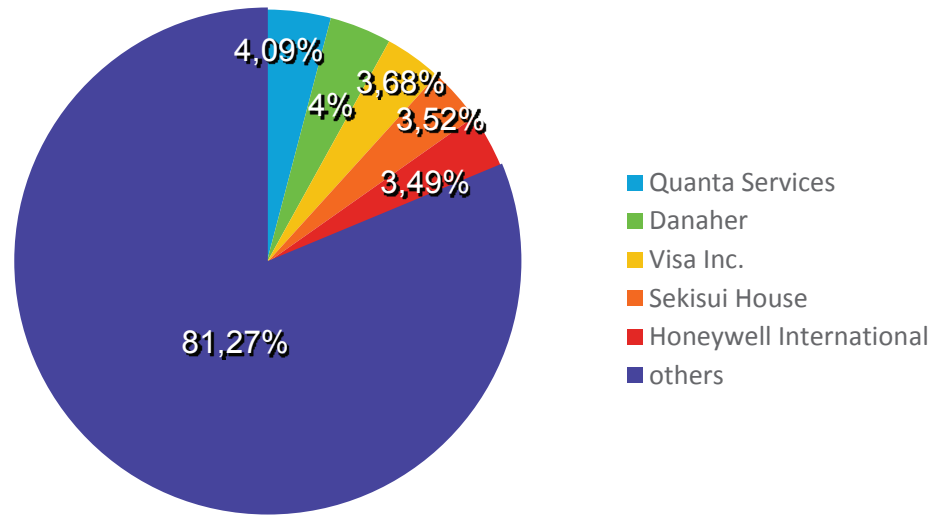

S o u r c e : www.sustainable-investment.org.

\section{ConCLUSION}

Swiss UBS bank and Deutsche Bank are perfect instances of financial institutions engaged in the protection of natural environment on the highest third level of involvement. Along with the Swiss Sarasin bank, they are main representatives of private banking sector as far as caring for the environment is concerned. They are engaged in the environment protection not only in the perspective of their own functioning but they also engage their customers in this activity by offering environmentally friendly products and services. Analyzing the environmentally-friendly offer of private banking institutions, raises the question: is it just a way to satisfy extravagant richest clients' requirements or also socially responsible activity generating the intended effects? The answer is not clear. By creating products, banks are primarily focused on meeting the needs of customers. So the eco-friendly offer is a response to the growing demand for such products. Based on the above it can be concluded that the involvement in activities to protect the environment at the third level of involvement is mainly dictated by the desire to gain a competitive advantage and profit. However, such an approach cannot be completely condemned since the primary objective of the financial institution is to satisfy the expectations of its shareholders by making profit. If this goal is achievable whilst taking care of the environment, such an institution can be called socially responsible. The effects of this activity will vary depending on the bank and the individual cha- 
racteristics of the offered product. However, there is no denying that private banking institutions have considerable strength of the investment associated with the huge amount of capital of their customers. Even if only a part of HNWI assets will be directed to finance environmental projects, the environment will certainly benefit from it. Moreover, the involvement of private banking in ecology often has a positive effect on the mass retail banking. It must be noted that private banks have the most innovative technological solutions and, through financial engineering, serving mainly the needs of this segment, offer the most modern products. Advanced solutions in private banking are frequently implemented at the lower segments of a bank. Thanks to this, mass retail customers may engage in the activity to protect the environment through its financial partners.

\section{REFERENCES}

Dziawgo L. (2003), Eco-Offers of Banks and Investment Funds. Poland \& International Trends, UMK, Torun.

Dziawgo L. (2005), Private Banking. Istota - Koncepcja - Funkcjonowanie, UMK, Toruń.

Dziawgo L. (2010), Zielony rynek finansowy. Ekologiczna ewolucja rynku finansowego, PWE, Warszawa.

Haigh M. and J. Hazelton (2004). Financial markets: A tool for social responsibility? Journal of Business Ethics, 52, 59-71. http://dx.doi.org/10.1023/B:BUSI $.0000033107 .22587 .0 \mathrm{~b}$.

Jeucken M. (2004), Sustainability in Finance. Banking on the Planet, Eburon Academic Publisher.

Krosinsky C., Robins N. (2008), Sustainable Investing. The Art of Long-Term Performance, Earthscan, London.

Sparkes R. (2002), Socially responsible investments; A global revolution, John Wiley \& Sons, Chichester.

2013 World Wealth Report (2013), http://www.worldwealthreport.com (accessed: 3.03.2014).

https://www.db.com (accessed: 3.03.2014).

http://www.sustainable-investment.org (accessed: 3.03.2014).

https://www.ubs.com (accessed: 3.03.2014). 
